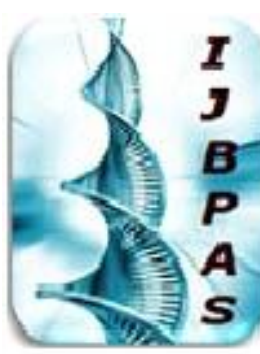

International Journal of Biology, Pharmacy and Allied Sciences (IJBPAS)

'A B Bridge Betusen Caboratory and QRando'

WWW.iibpas.com

\title{
MINALUNGAO NATIONAL PARK, NUEVA ECIJA, PHILIPPINES HOSTS SIX CHIROPTERA SPECIES
}

\author{
KHRISTINA G. JUDAN CRUZ AND LORD MER DG. PADER \\ Department of Biological Sciences, Central Luzon State University, Science City of Munoz, Nueva Ecija, Phil- \\ ippines \\ *Corresponding author: Khristina G. Judan Cruz: E-mail: karenjudancruz@gmail.com \\ Received 26 ${ }^{\text {th }}$ Feb. 2018; Revised $30^{\text {th }}$ March. 2018; Accepted 22 ${ }^{\text {nd }}$ April 2018; Available online $1^{\text {st }}$ July 2018 \\ https://doi.org/10.31032/IJBPAS/2018/7.7.4491
}

\begin{abstract}
Order Chiroptera is the most diverse mammalian order in the Philippines. However, the Chiropterans are also likely the most poorly identified mammals in the Philippines. Species of Chiroptera were collected from three (3) caves at Minalungao National Park, a 2000hectare protected area located at General Tinio, Nueva Ecija in Central Luzon, Philippines, which has not yet been identified for research, hence, limited existing published scientific studies. This is the first report of Chiropterans on Minalungao National Park, Philippines based on morphological characters, an update on the previously reported species based on a molecular marker, the mitochondrial cytochrome oxidase I (mtCOI). One endemic species is reported.

The study revealed a high diversity of chiropteran species at Minalungao. A total of 6 species of Chiroptera representing 2 suborders (Megachiroptera and Microchiroptera) and 5 families (Vespertilionidae, Hipposideridae, Emballonuridae, Pteropodidae, and Rhinolophidae) were identified using morphological characterization. These are: Miniopterus australis (Kulilit), Hipposideros pygmaeus (Tengang Baboy), Taphozous melanopogon (Ngusong Kabayo), Rhinolophus arcuatus (Panget), Ptenochirus jagori (Bangaag) and Rousettus amplexicaudus (Bayakan).
\end{abstract}

Keywords: Chiroptera; Minalungao National Park 


\section{INTRODUCTION}

Although known for its small land area, the Philippine archipelago is notable for the huge number of native endemic mammalian species and has the highest concentration of endemic mammals in a global scale with around 180 recorded mammal species; 110 of which are endemic $[1,2,3,4,5,6,7)$.

Chiroptera species frequently fill up a high percentage of the diversity of all the mammals around the world [8]. Chiroptera is regarded as the most diverse order of mammals in the Philippines, with 25 megachiropteran and 48 microchiropteran described species [6,8]. Roughly $40 \%$ of these species are endemic [8]. However, the Chiropterans are also accounted probably as the least identified order of mammals in the Philippines [1,9]. In fact, only 70 species of Chiroptera were reported from the Philippines when the latest checklist was prepared in 1992 [3, 9].

Chiroptera plays a very substantial role in the biosphere as part of the density and complexity of ecosystems and food webs therein. As part of biodiversity, it consumes fruits of trees as their nutrition and provides food, as well, to consumers such as humans. Protection of forest habitats must be prioritized worldwide for the safety of Chiropterans $[1,10]$. The dire need for conservation movements is caused by the devastation and damage of tropical forests and other anthropogenic threats such as hunting $[1,11]$.

Forest habitats have been acknowledged as principally essential for Chiroptera and a priority for conservation efforts globally [10] and the Philippines epitomizes an outstanding, if dismal, case. The forfeiture of forest habitats related to prevalent biodiversity have been well reported $[6,11]$, although, this in combination with the comparatively high endemism and a rate of species discovery which is amongst the greatest in the world [3] likens to an urgent necessity for conservation action. Accounted now as a hotspot in terms of biodiversity loss, conservation strategies are now being instigated in many areas in the Philippines. Among these is the establishment of national parks to help protect and conserve biodiversity.

Minalungao National Park located at General Tinio, Nueva Ecija in Central Luzon, Philippines, is a 2000-hectare protected area which has not yet been the focus for research and scientific studies. Presently, it serves as an ecotourism destination under the local government unit exhibiting stunning rock formations, fascinating river, and enchanting flora. It boasts high diversity of organisms that are con- 
densed on species-rich forests and rivers and is also considered as one of the last natural environments north of Manila.. It is an ecologically and biologically significant area where populations of globally threatened or geographically restricted species and undiscovered endemic species are expected to be found. It is a very good area for research particularly in studies for systematics, biodiversity conservation, microbiology, ecology, animal and plant physiology and biotechnology. These studies would be useful in the identification of plants and animal species that dwell in the area, as well as in determining the relationships and its ecological interactions.

While new species of Chiropterans have recently been reported, it is guessed that there are numerous species that may now be endangered and maybe extinct are still unknown $[1,9]$. Since it has been confirmed that the assessment of the number of species of Chiroptera in Philippines that are extinct or endangered is not conceivable, faunal surveys are recommended in practically all parts of the country [12]. Around $50 \%$ of the megachiropteran fauna in the Philippines is vastly threatened as an outcome of extensive deforestation and hunting $[8,10,13]$. On the other hand, the status of Microchiropteran fauna is poorly known [1,2] although several of endemic species were already recognized.
Currently, an initial listing of chiropteran species at Minalungao National Park based on molecular identification using the mitochondrial gene marker cytochorome oxidase 1 (CO1) was reported [14]. This is a first report on the chiropterans of based on morphological identification. With this study, it provides information on establishing its biodiversity that may be used to employ conservation strategies and eventually for the protection of Chiroptera at Minalungao National Park.

\section{MATERIALS AND METHODS}

\section{Collection of Samples}

The different species of Chiroptera were collected from three (3) caves at Minalungao National Park such as Maipit Cave, Minalungao Cave and Makatulang Cave. Exact location was determined using the Global Positioning System (GPS). Consequently, abiotic factors such as air temperature and humidity were determined using thermo-anemometer and sling psychrometer respectively. The guidelines on handling wild animals for research were strictly followed.

\section{Morphological Identification of Chirop- tera}

The following morphological characters were used in identifying the collected Chiroptera based on [9]: (1) Total length; (2) Body length; (3) Ear; (4) Tail; (5) Hindfoot; (6) Forearm. 


\section{RESULTS AND DISCUSSION}

A total of 6 species of Chiroptera representing 2 suborders (Megachiroptera and Microchiroptera) and 5 families (Vespertilionidae, Hipposideridae, Emballonuridae, Pteropodidae, and Rhinolophidae) were identified. Eight phenotypes with different local names were initially separated. However, through morphological external measurements, 3 of those phenotypes were classified under one species, Taphozous melanopogon Temminck, 1841 (Blackbearded tomb bat) with local names of Ngusong kabayo (brown), Ngusong kabayo (black). Other species identified with common and local names were Miniopterus australis Tommes, 1848 (Little BentWinged Bat/ Kulilit), Hipposideros pygmaeus Waterhouse, 1843 (Philippine pygmy roundleaf bat/ Ngusong Baboy), Rhinolophus arcuatus Peters, 1871 (Arcuate horseshoe bat/ no known local name), Ptenochirus jagori Peters, 1861 (Greater musky fruit bat/Bangaag) and Rousettus amplexicaudus E. Geoffroy, 1810 (Common rousette/ Bayakan).

Family

Miniopterus australis Tommes, 1848 (Little Bent-Winged Bat/Kulilit)

It has a total length of $87 \mathrm{~mm}$; tail of $11.3 \mathrm{~mm}$; hind foot of $6.2 \mathrm{~mm}$; ear of $13.4 \mathrm{~mm}$; forearm of $63.7 \mathrm{~mm}$. Similar to all Miniopterus, this species has very dark brown fur longer over the shoulders and top of the head than elsewhere on the body. Its tragus is small and is rounded and widest at the tip. The tip of its longest digit on the wing folds back rather firmly against the adjacent part of the wing, hence the English common name[15].

It nestles about $1000 \mathrm{~m}$ above sea level in agricultural areas, subsequent development, and principal forest, rarely comprising montane forest. It is frequently the most copious species in caves in distracted territories, with assessments habitually in the thousands. It often perches with Miniopterus schreibersii [4, 16, 17, $18,19,20]$. The echolocation call of this species from Laguna Province was defined [21]. They are geographically prevalent and common but reliant on caves [15].

Family

Hipposideridae

Hipposideros pygmaeus Waterhouse, 1843 (Philippine pygmy roundleaf bat/ Ngusong Baboy)

It has total length of $64.5 \mathrm{~mm}$, tail of $39.4 \mathrm{~mm}$, hind foot of $2 \mathrm{~mm}$, ear of 5.8 $\mathrm{mm}$, and forearm of $35.2 \mathrm{~mm}$. The tiniest species of Hipposideros is in the Philippines. The dorsal pelage has two colors, white or cream at the base and dark brown at the tips. The ventral pelage is medium brown, darkest at the base. There are two sets of leaflets lateral to the anterior noseleaf, the interior pair of which meet over- 
head the mouth (at the foot of the noseleaf) to form a incessant leaflet[22].

This species is not well characterized and identified. This species has been caught in caves close to lowland forest, secondary lowland forest, from sea level to at least $200 \mathrm{~m}$, over eroded limestone and soils[19, 20]. It is common but may be harmfully obstructed by the ruining of cave habitats. Lately there are increased captures, hence increased information. However, further field studies are critically required [22].

Family

Emballonuridae

Taphozous melanopogon Temminck, 1841 (Black-bearded tomb bat/Ngusong kabayo)

It has a total length of $89 \mathrm{~mm}$, tail of $29.3 \mathrm{~mm}$, hind foot of $19.3 \mathrm{~mm}$, ear of $14.5 \mathrm{~mm}$, and forearm of $63.5 \mathrm{~mm}$. It has a light brown fur with huge eyes, mild nasal area, and a low rounded tragus. It has a tail that is covered inside the tail membrane for the basal half but penetrates the membrane and lies on topmost of the membrane for the posterior half. Mature males have a spot of dark brown hair beneath the jowl [23].

It is widespread in urban regions, in areas with limestone caves, and in sea caves, at elevations at or below $150 \mathrm{~m}$. It often settles in narrow areas of caves and in churches, libraries, and other construc- tions with huge attics, effortlessly evident in hazy daylight $[18,19,20,24]$. It is prevalent in Asia and plentiful in the Philippines [23].

\section{Rousettus amplexicaudatus E. Geoffroy, 1810 (Common rousette/Bayakan)}

It has a total length of $100 \mathrm{~mm}$, tail of $13.6 \mathrm{~mm}$, ear of $13 \mathrm{~mm}$, forearm of 63.7 $\mathrm{mm}$, and hindfoot of $6.2 \mathrm{~mm}$. It is a huge fruit bat, but males are significantly bigger than females. Back fur is dark brown or grey, frequently having an ice-covered look, and is somewhat little and thin. The muzzle is elongated and jagged, and the ears are moderately long. The wing membranes are dark brown but almost translucent over the bones, which give the look of white stripes. It has a claw on the primary edge of the wing. It is passive when held and seldom bites[25].

It is common in rural and housing areas up to $500 \mathrm{~m}$ and rare in agricultural areas from 500 to $1600 \mathrm{~m}$. Furthermore, it is rarely in forest. All known nesting sites are in caves. Mature males are fewer than mature females. The species settles in huge groups (up to 100,000 per cave) and may have a harem type of reproducing system. They fly up to $25 \mathrm{~km}$ per night to forage. They naturally consume overriped fruit, producing less impairment in orchards than is usually thought of $[12,16$, $17,18,26,27,28 \mathrm{a} 28 \mathrm{~b}, 29]$. It is prevalent 
in Indo-Australia. It is locally abundant, normally firm, but exposed to extreme hunting at some cave habitats [30].

\section{Ptenochirus jagori Peters, 1861 (Greater} musky fruit bat/Bangaag)

It has a total length of $117.6 \mathrm{~mm}$, tail of $16.9 \mathrm{~mm}$, ear of $14.6 \mathrm{~mm}$, forearm of $87.6 \mathrm{~mm}$, and hindfoot of $12.1 \mathrm{~mm}$. It is an objectively huge fruit bat with a wideranging, black head and stouty snout. Orally, four upper and two lower incisors are present. Adults have a shoulder ruff of fur, typically with a gland below the ruff that secretes a yellow greasy substance, which marks the ruff. A smell of cinnamon is a common distinguishing characteristic, especially on males. Males are somewhat bigger and darker than females[31].

It is plentiful in primary forest, widespread in secondary forest, frequently seen in farmland and urban parks and domestic areas. It is seen from sea level to at least $1950 \mathrm{~m}$. Frequently, it is one of the most populous bats in lowland forest, with densities of 1 to over 3 per hectare. Mature males have full length about half the size of those of mature females. It consumes greatly on figs and other fruits such as banana (Musa spp.). Perching spots have been discovered in hollow trees and in narrow caves in limestone and clay panels. Genomic records infer equally high levels of gene flow throughout the Philippines [9,
$12,17,20,26,27,28 \mathrm{a}, 28 \mathrm{~b}, 32,33,34]$. Its population is big and commonly constant, extensive, and forbearing of seriously bothered habitat [31].

\section{Family \\ Rhinolophidae \\ Rhinolophus arcuatus Peters, 1871 (Ar- cuate horseshoe bat; no known local name)}

It is a medium to small Rhinolophus, with total length of $61 \mathrm{~mm}$, hind foot of $19.6 \mathrm{~mm}$, ear of $39.2 \mathrm{~mm}$, and forearm of $56.4 \mathrm{~mm}$. The fur is generally moderate brown posteriorly, and somewhat lighter anteriorly. The noseleaf is almost as broad as the muzzle, and there are no additional leaflets [35].

It can be seen from sea level to $1950 \mathrm{~m}$, in farmlands, second growth, and primary forest, frequently abundant in the lowlands but rarely in montane and mossy forest. Perching spots are in caves, fissures, rocky ledges, and in deep trees. It is more effortlessly caught in harp ploys than in haze nets $[4,16,17,18,19,21,28 \mathrm{a}$, $28 \mathrm{~b}, 36,37,38]$. The echolocation calls of specimens from Laguna Province, Luzon were defined [21]. They are prevalent and locally common [35].

A total of 6 chiropterans were identified at Minalungao National Park, Philippines using morphological characters. This embodies nearly 9\% of the Philippine bat community out of the 68 species re- 
ported [39]. The Philippine bat fauna unveils remarkably great rate of endemism, definitely among the utmost in the world [40]. In fact, one species reported in this study, Ptenochirus jagori, is endemic to the Philippines [41]. This great level of bat diversity and endemism may be caused by optimum environmental conditions of the region. Chiroptera predominantly occupies jungles and rich areas such as rivers that give an essential territory for bat fauna by giving uninterrupted treasured resources. Riparian habitats, shown by the Minalungao area that comprises rivers, are significant habitats for many species of Chiroptera because it provides food and water. Bat searching activity ensues prominently in this type of habitat [42]. Moreover, high diversity of the chiropterans maybe caused by the occurrence of trees and insects in the area that chiefly constitutes their diet.

Furthermore, this diversity of bats in the area shows the quality of the environment. With its environmental significance on diverse habitats, Chiroptera is a good indicator of integrity of natural communities because of its number of resource qualities such as nestling, irrigating, and nourishing habitats presenting rapid population variations if supply attribute is misplaced [43]. The significance of recording the existing species in the area is signified. Because of the frugi- vorous diet of some of the species of Chiroptera, they are likewise referred to as several of the most essential seed dispersors, crucial for the redevelopment of the forests and establishment of the fresh spaces by plants [44]. The occurrence of the bat species in the caves they were collected gives us an idea of the diet of the chiropterans and the species of plants and animals surrounding the location.

Since only morphological measurements were employed in the identification, more molecular studies on these species, aside from the initial molecular barcoding studies done [14], are now underway to accurately verify species assignment as 8 initial phenotypes were characterized with three different phenotypes were classified only under one species, $T$. melanopogon. Morphological identification may be unreliable and can be challenging and it is not always conceivable to classify bats only by outward characters [45] as specific species may be very comparable in form, hence species assignment as well as phylogeny can only be fixed using up-to-date molecular methods [45]. Through succeeding researches, it is hoped that this opens up the idea of discovering more endemic and unrecorded chiropterans in the Philippines, particularly at Minalungao National Park as well as design- 
ing strategies for its conservation and management.

\section{CONCLUSION}

A total of 6 species of Chiroptera representing 2 suborders (Megachiroptera and Microchiroptera) and 5 families (Vespertilionidae, Hipposideridae, Emballonuridae, Pteropodidae, and Rhinolophidae) were identified using morphological characters. These are: Miniopterus australis (Kulilit), Hipposideros pygmaeus (Tengang Baboy), Taphozous melanopogon (Ngusong Kabayo), Rhinolophus arcuatus (Panget), Ptenochirus jagori (Bangaag) and Rousettus amplexicaudus (Bayakan). One endemic species is reported.

\section{ACKNOWLEDGEMENT}

The authors would like to acknowledge the following: Dr. Sweepea Veluz of the National Museum of the Philippines, Manila for the authentication of the specimens and for sharing her technical expertise; Prof. Thaddeus Carvajal of De La Salle UniversityManila, Philippines; Department of Environment and Natural Resources CENRO, Cabanatuan City, Nueva Ecija, Philippines; the Department of Biological Sciences, Central Luzon State University, Science City of Munoz, Nueva Ecija; and most of all, the people of Minalungao National Park, General Tino, Nueva Ecija, Philippines for their assistance for the completion of the research, this piece of work is dedicated to them.

\section{REFERENCES}

[1] Turner, CS, Tamblyn A, Dray R, Maunder L, Raines PS. 2003. The biodiversity of the Upper ImbangCaliban Watershed, North Negros Forest Reserve, Negros Occidental, Philippines Coral Cay Conservation. London.

[2] Heaney LR. 1993. Biodiversity patterns and the conservation of mammals in the Philippines. Asia Life Sciences. 2, 261-274.

[3] Heaney LR, Balete DS and Dans ATL. 1997. Terrestrial Mammals. In Philippine Red Data Book. Wildlife Conservation Society of the Philippines, Bookmark Inc, Philippines.

[4] Esselstyn JA, Widmann P and Heaney LR. 2004. The Mammals of Palawan Island, Philippines. Proceedings of the Biological Society of Washington. 117(3):271-302.

[5] Heaney LR, Balete DS, Dolar ML, Alcala AC, Dans ATL, Gonzales PC, Ingle NR, Lepiten MV, Oliver WLR, Ong PS, Rickart EA, Tabaranza Jr BR and Utzurrum RCB. 1998. A synopsis of the mammalian fauna of the Philippine Islands. Fieldiana: Zoology, New Series. 88:1-61. 
[6] Heaney LR and Regalado JC Jr. 1998.Vanishing Treasures of the Philippine Rain Forest. The Field Museum, Chicago.88 pp.

[7] Mittermeier RA, Robles Gil P and Mittermeier CG. 1997. Megadiversity: Earth's biologically wealthiest nations. CEMEX, Monterrey, Mexico.501 pp.

[8] O’Malley R., King T, Turner CS, Tyler S, Benares J, Cummings $\mathrm{M}$ and Raines P. 2006. The Diversity and Distribution of the Fruit Bat Fauna (Mammalia, Chiroptera, Megachiroptera) of Danjugan Island, Cauayan, Negros Occidental, Philippines. Biodiversity \& Conservation, 15(1): 43-56 pp.

[9] Ingle NR and Heaney LR. 1992. A Key to the Bats of the Philippine Islands. Fieldiana: Zoology, 69, 1-44.

[10] Mickleburgh SP, Hutson AM and Racey PA. 2002. A review of the global conservation of status of bats. Oryx, 36(1): 18-34 pp. DOI: http://dx.doi.org/10.1017/ S0030605302000054

[11] Oliver WLR and Heaney LR. 1996. Biodiversity and Conservation in the Philippines.International Zoo News, 43, 329-337.

[12] Heideman PD and Heaney LR.1989. Population biology and estimates of abundance of fruit bats (Pteropodidae) in Philippine submontane rainforest. Journal of Zoology, London, 218: 565-586.

[13] Mendoza MM, Mallari NAD. 1997. Philippine Red Data Book. Wildlife Conservation Society of the Philippines Bookmark Inc. Philippines

[14] Pader LDG, Banson CJGC, Pranilla WAP, Barroga KJD, Morales ND Jr., Martin LO, Cumbe AP, Medel NFS , Ventura ZA, Battad ZG, And Judan Cruz KG. 2017. DNA Barcoding of Chiropterans at Minalungao National Park, Nueva Ecija, Philippines. International Journal of Agricultural Technology 2017 Vol. 13(7.3): 2341-2344

[15] Tomes K. 1858. Mammal Species of the World: A Taxonomic and Geographic Reference. Proc. Zool. Soc. Lond., 12, 125.

[16] Heaney LR, Gonzales PC, Utzurrum RCB and Rickart EA. 1991. The mammals of Catanduanes Island: Implications for the biogeographyof small land-bridge islands in the Philippines. Proceedings of the Biological Society of Washington, 104: 399415. 
[17] Lepiten MV. 1995. The mammals of Siquijor Island, central Philippines.Sylvatrop, 5: 1-17.

[18] Rickart EA, Heaney LR, Balete DS and Tabaranza Jr BR. 2011.Small Mammal Diversity Along an Elevational Gradient in Northern Luzon, Philippines. DOI: http:// dx.doi.org/10.1016/j.mambio.2010.0 1.006 .

[19] Sanborn CC. 1952. Philippine Zoological expedition 1946-1947. Mammals. Fieldiana: Zoology, 33: 89-158.

[20] Taylor EH. 1934. Philippine land mammals. Monographs of the Bureau of Science, Manila, 30: 1548.

[21] Sedlock JL. 2001. Inventory of insectivorous bats on Mount Makiling, Philippines using echolocation call signatures and a new tunnel trap. Acta Chiropterologica, 3: 163-178.

[22] Waterhouse GR. 1843. On various species of bats collected by $\mathrm{H}$ Cuming, Esq in the Philippine Is. Proc Zool Soc Lond 1843: 66- 69

[23] Temminck L. 1841. South Asian Mammals: Their Diversity, Distribution, and Status. Monogr.Mamm.,2:287.
[24] Lawrence BL. 1939. Collections from the Philippine Islands.Mammals.Bulletin of the Museum of Comparative Zoology, 86: 28-73.

[25] Geoffroy, E. 1810. Ptenochirus jagori. Ann. Mus. Hist. Nat. Paris, $15: 96$

[26] Heaney LR, Heideman PD, Rickart EA, Utzurrum RCB, and Klompen JSH. 1989. Elevational zonation of mammals in the central Philippines. Journal of Tropical Ecology, 5: 259280.

[27] Heaney LR, Balete DS, Rickart EA, Utzurrum RCB and Gonzales PC. 1999. Mammalian diversity on Mount Isarog, a threatened center of endemism on southern Luzon Island, Philippines. Fieldiana: Zoology, new series, 95: 1-62.

[28a] Heaney LR, Tabaranza BR Jr, Rickart EA, Balete DS and Ingle NR. 2006. The mammals of Mt. Kitanglad Nature Park, Mindanao, Philippines. Fieldiana: Zoology, new series, 112: 1-63

[28b] Heaney LR, Tabaranza BR Jr, Balete DS and Rigertis N. 2006. Synopsis and biogeography of the mammals of Camiguin Island. Fieldiana: Zoology new series, 106: $28-48$. 
[29] Heideman PD and Utzurrum RCB. 2003. Seasonality and synchrony of reproduction in three species of nectarivorous Philippines bats. BMC Ecology, 3, accessed at http://www.biomedcentral.com/1472 $-6785 / 3 / 11$.

[30] Utzurrum RCB. 1992. Conservation status of Philippine fruit bat (Pteropodidae). Silliman Journal, 36: 27-45.

[31] Peters W. 1861.Rousettus amplexicaudatus.Monatsb.Preuss.Ak ad.Wiss. Berlin, 8:707.

[32] Heidemen, P. D., and Powell, K. S. (1998). Age-specific reproductive strategies and delayed embryonic development in an Old World fruit bat, Ptenochirus jagori. Journal of Mammalogy, 79: 295-311.

[33] Mudar, K. M. and Allen, M. S. (1986). A list of bats from northeastern Luzon, Philippines. Mammalia, 50: 219-225.

[34] Roberts TE. 2006. History, ocean channels, and distance determine phylogeographic patterns in three widespread Philippine fruit bats (Pteropodidae). Molecular Ecology, 15: 2183-2199.

[35] Peters W. 1871. Rhinolophus arcuatus. Monatsb.Preuss.Akad. Wiss.Berlin, 12:90.
[36] Duya MRM, Alviola PA, Duya MV, Balete DS and Heaney LR. 2007. Report on a survey of mammals of the Sierra Madre Range, Luzon Island, Philippines. Banwa, 4: 41-68.

[37] Sedlock JL, Weyandt SE, Cororan L, Damerow M, Hwa S and Pauli B. 2008. Bat diversity in tropical forest and agro-pastoral habitats within a protected area in the Philippines. Acta Chiropterologica, 10: 349-358.

[38] Tamblyn, A, Turner CS, Dray R and Raines PS. 2003. The bats (Mammalia, Chiroptera) of the Upper Imbang-Caliban Watershed, North Negros Forest Reserve, Negros Occidental, Philippines. Silliman Journal, 44: 100-116.

[39] Heaney, L. R., and P. D. Heideman. 1987. Philippine fruit bats, endangered and extinct. Bats, 5: 3-5.

[40] Heaney L.R., Dolar, M.L., Balete, D.S., Esselstyn, J.A., Rickart, A.E., Sedlock, J.L., 2010. Synopsis of Philippine Mammals. The Field Museum of Natural History in cooperation with the Philippine Department of Environment and Natural Resources - Protected Areas and Wildlife Bureau.

[41] Lobite NJS, Lubos LC, Japos GV. 2013. A preliminary Assessment of 
the Chiropteran Fauna of the Oro River, Cagayan de Oro, Philippines. Asian Journal of Biodiversity, 2, 119-134.

[42] Racey PA. 1998. The importance of the riparian environment as a habitat for European bats.Symp. Zool. Soc. London, 71: 69-91.

[43] Hutson AM, Mickleburgh SP and Racey PA. 2001. Microchiropteran Bats: Global Status Survey and ConservationAction Plan. IUCN, Gland, Switzerland.

[44] Altringham JD. 1996. Bats: Biology and Behaviour. Oxford University Press Inc, New York, 262 pp.

[45] Dietz C and von Herversen O. 2004. Illustrated identification key to the bats of Europe. Electronic Publication Version 1.0. Tuebingen \& Erlangen (Germany). 